\title{
Effect of gellan, xanthan or locust bean gum and/or emulsified maize oil on proteins edible films properties
}

\author{
Erick C. Téllez-Rangel, Eva Rodríguez-Huezo, Alfonso Totosaus* \\ Food Science Lab \& Pilot Plant. Tecnológico Estudios Superiores Ecatepec. Av. Tecnológico esq. Av. Central s/n., Ecatepec 55210, México.
}

\section{A B S T R A C T}

\begin{abstract}
Composite edible films properties depend on the functionality of the different components employed, like protein and/or polysaccharides, and/or lipids, in order to enhance mechanical properties. Collagen and egg white albumin edible films were elaborated with three different gums (locust bean gum, gellan gum or xanthan gum), with or without emulsified oil. Egg white albumin edible films were more opaque, less permeable and less soluble than collagen samples. Collagen edible films were tougher and ductile/extensible than egg white albumin samples. Emulsified oil increased opacity and decrease water vapor permeability. Although inherent differences related to protein type on water vapor permeability and mechanical properties, gellan and xanthan gums improved mechanical properties resulting in more resistant samples. Water vapor permeability was higher in samples with no-charged polysaccharide, locust bean gum, where other kind of interactions different to electrostatic ones occurred. Changes due to the presence of a lipid phase increased all tensile parameters of emulsified films based are due to strong interaction between the biopolymers and the lipid particles as a cross-linking effect.
\end{abstract}

Keywords: Edible film; Composite films; Proteins; Gums; Emulsion; Physicochemical properties; Mechanical properties

\section{INTRODUCTION}

Edible film or coating is a thin and continuous layer of edible material placed on food surface for preservation. Edible films are stand-alone films whereas coatings are formed directly on the food surface. Specific reasons for this procedure could include controlling mass transfer and surface conditions, carry food ingredients or additives, provide physical and mechanical protection, and sensorial improvement (Fernández-Pan et al., 2011). A broad and proper definition for edible film is any GRAS material used to enrobing food to extend shelf-life and that may be eaten together with the food, providing replacement and/ or fortification of natural layers to avoid moisture losses and control gases exchange, to prevent loss of important components, with a thickness lower than $0.3 \mathrm{~mm}$ (Pavlath and Orts, 2009).

Gellan gum and xanthan gum are produced by biotechnological processes since bacteria have been an important source of exopolysaccharides since the early 1970s. Gellan gum is a linear anionic heteropolysaccharide of ca. $0.5 \times 10^{6} \mathrm{Da}$. It comprises the monosaccharide building units glucose, glucuronic acid and rhamnose in a molar ratio of 2:1:1 with a tetrasaccharide repeating unit. Xanthan gum is composed of a $1-4$-linked $\beta$-D-glucose backbone (like cellulose), with side-chains containing two mannoses and one glucuronic acid, where the pyruvic acid residues carried on half of the terminal mannose units represent $\sim 60 \%$ of the molecule, with a molecular weight of ca. $2.5 \times 10^{6} \mathrm{Da}$ with low polydispersity. Galactomannans are linear polysaccharides based on a backbone of $\beta(1-4)$-linked $\mathrm{D}$-mannose residues, with single $\alpha$-D-galactose residues linked to the chain by $\mathrm{C}-1$ via a glycosidic bond to $\mathrm{C}-6$ of mannose, where the degree of galactose substitution varies. In locust bean gum, a commercially important galactomannan considered a GRAS food ingredient by the FDA, the average galactose to mannose ratio is $1: 4$, with a molecular weight of $1.94 \times 10^{6} \mathrm{Da}$ (Nussinovith, 1997). Food applications are particular for each gum, but their main feature is like thickness agents, since gel formation requires in most cases requires temperature or ions presence, at least for gellan gum.

\footnotetext{
*Corresponding author:

Alfonso Totosaus, Food Science Lab \& Pilot Plant. Tecnológico Estudios Superiores Ecatepec. Av. Tecnológico esq. Av. Central s/n., Ecatepec 55210, México. E-mail: atotosaus@tese.edu.mx
}

Received: 26 July 2017 ; $\quad$ Accepted: 31 March 2018 
Biopolymers like proteins and polysaccharides are present in many kinds of foods systems, and both macromolecules contribute to the structure, texture and stability of food through their thickening behavior, gelling and surface properties (Doublier et al., 2000). Macroscopic properties of foods depend directly from biopolymers interaction, since food products can be structured on a mesoscopic level with special macroscopical and rheological properties (de Kruif and Tuinier, 2001).

In this view, protein-polysaccharide interactions could be employed to develop different structures in emulsified edible films. Nonetheless, only few previous studies had employed gellan gum, xanthan gum or locust bean gum in mixed edible films. For example, in gellan gum/gelatin edible films, higher gellan gum proportions resulted in more soluble and elastic but less brittle films (Lee et al., 2004). In same manner, incorporation of bee wax in gellan gum edible films improved water vapor permeability, but decrease tensile strength (Yang and Paulson, 2000). For xanthan gum, the main combination seems to be with starches, increasing solubility and enhancing mechanical properties (Veiga-Santos et al., 2005). Locust bean gum has been employed with kappa-carrageenan, improving tensile strength and reducing water vapor permeability (Martins et al., 2012).

Edible film casting depends on rheology and flow of filmogenic solution. Since biopolymer complexes combine the functional properties of each component, the resulting complexes functional properties are generally enhanced, the use of protein-polysaccharide complexes for the production of edible films seems to be a good mean for improving their physicochemical properties and further studies are expected to confirm it (Schmitt et al., 1998). Edible films properties depend on the functionality of the different components employed, like protein and polysaccharides, in order to enhance mechanical properties (Pérez-Gago, 2012). In this view, mixture of various biopolymers results in a multicomponent edible film with different properties derived from cooperative functionalities. Polysaccharides impart structural cohesion serving as structural matrix, and proteins give rise to tight structure due their intra- and intermolecular interactions (Wu et al., 2002; Giancone et al., 2008). Proteins and polysaccharides generally form films with good mechanical properties but they form poor moisture barriers, because of their hydrophilicity. Conversely, lipids, as hydrophobic substances, height moisture barrier properties, but have less effective mechanical properties. Lipids can form a layer over the hydrocolloid matrix (bilayer films or laminated) or can be dispersed into the matrix as emulsified films, in which the lipid is uniformly dispersed throughout the edible barrier) (Khwaldia et al., 2004; Kokoszka et al., 2010). Since foods are dynamic systems with limited shelf life, specific packaging needs as besides barrier properties of edible films are necessary to extend shelf life, since edible films prevent moisture loss and decrease oxygen permeability (Lacroix and Le Tien, 2005).

Based on the stated arguments, this research proposed to determinate the effect of different gums, locust bean gum, gellan gum, or xanthan gum, on physical and mechanical properties of protein edible films elaborated with or without emulsified oil. This because the interaction between protein-polysaccharides in emulsified edible films is a gap in that needs to be more studied in order to develop of more versatile edible packaging films.

\section{MATERIALS AND METHODS}

\section{Edible protein film elaboration with gum and/or emulsified oil}

Egg albumen edible film was elaborated as described by Handa et al. (1999), with few modifications. Campeon ${ }^{\circledR}$ egg albumen (Alimentos Deshidratados, Mexico City) was dissolved in distilled water $(8.33 \%, \mathrm{w} / \mathrm{v})$, with two drops of silicon antifoam to avoid foam generation. After complete dissolution, glycerol $(50 \% \mathrm{v} / \mathrm{w}$, based on protein weight) was added as plasticizer before adjust $\mathrm{pH}$ to 11.25 with $\mathrm{NaOH}$. Protein-glycerol solution was centrifuged at 2,000×g during $10 \mathrm{~min}$, discarding the un-solubilized pellet.

Collagen edible film was elaborated according to Díaz et al. (2011) methodology. Collagen protein CC400 (Interalimen SA, Mexico City) was dissolved in distilled water $(4.91 \%$, $\mathrm{w} / \mathrm{v})$ in water bath at $60^{\circ} \mathrm{C}$ during $20 \mathrm{~min}$, filtrating nondissolved material. Glycerol ( $50 \% \mathrm{v} / \mathrm{w}$, according to protein weight) was added and dissolved during $10 \mathrm{~min}$.

To each protein solution, $0.1 \%$ (w/v) of high acyl Gellan gum Kelcogel LT100 (CP Kelco, Atlanta), Xanthan gum Keltrol F (CP Kelco, Atlanta) or Viscogum LBG Locust bean gum (Cargill, Kansas City) were dissolved. Edible films with emulsified oil were formed incorporating to protein-gum solutions with $3 \%(\mathrm{v} / \mathrm{v})$ of maize oil La Gloria (Corfuerte SA, Monterrey) and emulsified during 3 min with an Oster homogenizator (12,000 rpm, Sunbean Mexicana, Tlalnepantla).

Edible films were prepared according to the casting technique, dehydrating the filmogenic protein-plasticizer or protein-plasticizer-gum solutions. Solutions were poured in glass plates $(12 \times 12 \mathrm{~cm})$ and dehydrated at room temperature $\left(25 \pm 1{ }^{\circ} \mathrm{C}\right)$ at $55 \pm 5 \% \mathrm{RH}$ during $48 \mathrm{~h}$. Edible films were stored in polyethylene bags in a desiccator until further analysis. 


\section{Opacity and water vapor permeability}

Film samples were placed in an acrylic cell without front and back walls. Samples were scanned from 400 to $800 \mathrm{~nm}$ in a Genesys 10 spectrophotometer (Thermo Fisher Scientific, Waltham), reporting film opacity as the area under the curve divided by average film thickness (Pereda et al., 2012). Film thickness was determined as the average of at least 5 random locations measure employing a Mitutoyo IP 65 digital micrometer (Mitutoyo, Kanagawa).

Water vapor permeability was determined by gravimetric cup method according to Gennadios et al. (1996). Film samples were mounted on glass flasks filled with distilled water to one $\mathrm{cm}$ from the film surface. Flasks were placed at $25^{\circ} \mathrm{C}$ and $50 \% \mathrm{RH}$. Flasks were weighted during 6-8 h to calculate the slope of the steady-state (linear) region of the weight loss vs. time curves. Water vapor permeability was calculated as:

$$
\left.\mathrm{WVP}_{\mathrm{g}} / \mathrm{P}_{\text {asm }}\right)=\frac{(\mathrm{WVTR} \times \mathrm{L})}{\varnothing_{\mathrm{P}}}
$$

Where WVPR is the water vapor permeability rate (calculated as slope of water vapor loss multiplied by the exposed area), $\mathrm{L}$ is the average film thickness, and $\Delta \mathrm{p}$ is the vapor pressure difference across the film (calculated base on the temperature and $\mathrm{RH}$ inside and outside the flask).

\section{Total soluble material and soluble protein}

The method reported by Jangchud and Chinnan (1999) was adapted. Film samples $(2 \times 2 \mathrm{~cm})$ were dried at $70^{\circ} \mathrm{C}$ overnight and weighted before being directly immersed in distilled water $\left(30 \mathrm{~mL}, 0.02 \% \mathrm{NaN}_{3}\right)$ during $24 \mathrm{~h}$. After this time, undissolved material was retired and dried at $105{ }^{\circ} \mathrm{C}$ during $24 \mathrm{~h}$ to determinate the weight of dry matter, which was not solubilized in water. The weight of dry matter solubilized was calculated by subtracting the weight of dry matter not solubilized from the weight of initial dry matter and reported on initial dry weight basis, reporting the total soluble material as the percentage of the film dry mass dissolved after $24 \mathrm{~h}$ immersion in distilled water.

From the dissolved protein for total soluble material, the dissolved protein was determined employing biuret method (Gornall et al., 1949). Soluble protein was reported as (Jungchud and Chinnan, 1999):

$$
\begin{aligned}
& \text { Protein concentration } \\
& \text { Soluble protein }(\%)=\frac{(\text { protein weight in } 30 \mathrm{~mL})}{\text { Flim initial weight }} \\
& \times \% \text { Protein in } \mathrm{flim} \\
& \times \% \text { F lim dry material }
\end{aligned}
$$

\section{Puncture force and puncture deformation}

Films force and deformation at the breaking point were determined according to the reported by Sobral et al., (2012). Samples were attached to a $52.4 \mathrm{~mm}$ of diameter acrylic cell and perforated in the center with a $3 \mathrm{~mm}$ of diameter aluminum probe at a constant speed of one $\mathrm{mm} / \mathrm{s}$ in a Brookfield LFRA 4500 (Brookfield Engineering Laboratories, Middleboro). From the force-distance curves the puncture force and probe displacement (D) were calculated. Film initial length $\left(1_{0}, 26.3 \mathrm{~mm}\right.$, equal to acrylic cell radius) was employed as well to calculate the puncture deformation as:

Puncture deformation $(\%)=\frac{\Delta \mathrm{I}}{1_{0}}=\frac{\sqrt{\mathrm{D}^{2}+1_{0}^{2}-1_{0}}}{1_{0}}$

\section{Tensile strength and percentage of elongation}

Film resistance and enlargement rupture or breakdown were determined employing a Chatillon TCM 200 motorized test stand equipped with a Chatillon DFIS 200 digital force gauge (Ametek, Largo, Florida), according to the described by Gennadios et al. (1993). Charge and extension of the film (100 mm length and $26 \mathrm{~mm}$ wide) was determined at a constant speed rate of $50 \mathrm{~mm} / \mathrm{min}$ and an initial grip separation of $50 \mathrm{~mm}$. Extension force was calculated as the rate of the maximum charge and the transversal sectional area. Tensile strength was calculated by dividing the maximum force at break by the cross-sectional area (thickness in $\mathrm{mm} \times 26 \mathrm{~mm}$ ). Percent elongation at break was calculated dividing extension values by the initial grip separation $(50 \mathrm{~mm})$ and multiplying by 100 .

\section{Fourier transform infra-red spectroscopy and optical microscopy}

Single-beam spectra of the edible films samples were collected against a background of air in an infra-red spectrophotomer Buck M530 (Buck Scientific, East Norwalk), scanning from 4000 to $1000 \mathrm{~cm}^{-1}$, at a nominal resolution of $10 \mathrm{~cm}^{-1}$.

Samples of edible films were observed in a Mitutoyo Ultrapan FS110 microscope (Mitutoyo, Kanagawa) at 50×.

\section{Experimental design}

A complete factorial design was employed to determine the effect of protein, added gum and emulsified oil on edible film properties. The proposed model was:

$$
\mathrm{y}_{\mathrm{ijk}}=1 / 4+ \pm_{\mathrm{i}}+^{2}{ }_{\mathrm{j}}+{ }^{3}{ }_{\mathrm{k}}+\epsilon_{\mathrm{ijk}}
$$

where $y_{i j k}$ represents the functional properties for the $i$ th protein type (collagen or egg white), the $j$ th type of gum (no gum, locust bean gum, gellan or xanthan), and the kth oil presence (emulsified oil or not); $\mu$ is the overall mean; $\alpha, \beta$, and $\gamma_{k}$ are the main effects of protein, gum and emulsified 
oil, respectively; $\in_{i j k}$ is the residual or error terms assumed to be normally distributed with mean and variance $\sigma^{2}$ equal to zero (Der and Everitt, 2002). Results were analyzed with the PROC ANOVA procedure in SAS Software ver. 8.0 (SAS System, Cary, USA). Significant differences between means were determined by the Duncan means test.

\section{RESULTS AND DISCUSSION}

\section{Opacity and water vapor permeability}

Edible films opacity was significantly $(\mathrm{P}<0.05)$ lower for collagen samples. Edible films with emulsified oil were significantly $(\mathrm{P}<0.05)$ less translucent. Opacity values were significantly $(\mathrm{P}<0.05)$ higher for control samples, and more translucent films were those containing locust bean gum (Table 1). Opacity of emulsified oil containing films were higher than for no-emulsified oil samples, since the transparency of the film matrix was affected by the droplets dispersion, concomitantly restricting light transmission throughout the film, since the dispersed non-miscible phase promoted opacity as a function of differences in phases' refractive index and dispersed phase particle size (Pereda et al., 2012). Films transparency was determined by the absorption spectrum in the visible range, and lower opacity is related to lower absorption curve value (Zaritzky, 2011). To incorporate gums into edible film formulation decreased opacity probably related to a lower cohesive energy density and a higher free volume among biopolymer chains (Wang et al., 2007a).

For water vapor permeability (WVP), collagen edible films were significantly $(\mathrm{P}<0.05)$ more permeable than egg albumen edible films. Significantly $(\mathrm{P}<0.05)$ lower permeability values were obtained in emulsified oil samples. When gums were added into edible film formulation, significantly $(\mathrm{P}<0.05)$ higher values were observed, with higher WVP was for gellan gum samples (Table 1). Lower WVP values were obtained in emulsified oil gum containing edible films. The lower continuity of the protein network provoked by lipid globules dispersed in the protein matrix is the result of two factors. One, the heterogeneous distribution of lipid globules with high particle size into a protein matrix could affect the structural cohesion of the polymeric matrix, affecting WVP. Two, aggregation of lipid globules into films decreases the film tortuosity (structure of porous media) having an effect on water diffusion and thus WVP (Khwaldia et al., 2004). On the other hand, incorporation of polysaccharides affects water vapor permeability values improving barrier properties of edible films (Fabra et al., 2008). Locust bean gum, a neutral polysaccharide, presented higher WVP values. Anionic gums as xanthan and gellan interact by charge with proteins resulting in a more compact structure. Moreover, both proteins are above their isoelectric point, carrying out a negative charge as well, where the free volume (vacant space that is not occupied by the microstructure of the polymer molecule) acts as a store for gas molecules that has to change continuously to promote gas transport throughout the film (Wang et al., 2007a).

Permeance is the mechanism by which a gas migrates through a continuous barrier, consisting in gas dissolving into one side of the barrier, diffusing through that barrier by random motion, and escaping out the other side of the barrier, where the driving force is the difference in partial pressure of the gas on the two surfaces of the barrier (Hagenmaier, 2012). In same manner, edible films contain in their formulation hydrophilic components, such as proteins or polysaccharides, and since water vapor flux through hydrophilic films varies non-linearly with water vapor partial pressure gradient, and hence, permeability is not an inherent property of hydrophilic films (Habig McHugh et al., 1993). The incorporation of emulsified oil at the concentrations and experimental conditions employed decreased WVP, since emulsified oil droplets were stable during and after emulsion prior to casting of edible films. This affected the cohesion of the protein matrix reducing the water vapor permeability.

\section{Total soluble material and soluble protein}

Total soluble material was significantly $(\mathrm{P}<0.05)$ lower for egg albumin samples. Emulsified oil resulted in significantly $(\mathrm{P}<0.05)$ less total soluble material in edible films. The incorporation of gums resulted in significantly $(\mathrm{P}<0.05)$ higher total soluble material values, where locust bean gum presented the higher values (Table 2). For soluble protein, collagen samples presented the significantly $(\mathrm{P}<0.05)$ higher values. The soluble protein in edible films with emulsified oil significantly $(\mathrm{P}<0.05)$ increased in no added oil samples. Incorporation of gum into edible film formulation resulted in significantly $(\mathrm{P}<0.05)$ lower values for soluble protein, where gums with stronger electrostatic interaction presented the lower solubility values (Table 2 ).

When gums were added into edible film formulation the total soluble material increased due to their hygroscopic character, but soluble protein decreased. Emulsified oil decreased this parameter as well, since proteins were occupied stabilizing the emulsion interface. Edible films containing emulsified oil were less soluble than control film since oil decreased the hydrophilic nature of the sample (Tural and Turhan, 2017). The more efficient composite film structure obtained by emulsion creaming and coalescence is affected by the presence of an emulsifier (proteins and plasticizer) probably led to smaller particles and less aggregation (Kokoszka et al., 2010). Gums like locust bean gum, gellan gum or xanthan gum employed 
Téllez-Rangel, et al.

Table 1: Effect of emulsified oil on protein-gum edible film opacity and water vapor permeability

\begin{tabular}{|c|c|c|c|c|c|c|c|c|c|}
\hline \multirow[t]{2}{*}{ Protein } & \multirow[t]{2}{*}{ Treatment } & \multicolumn{4}{|c|}{ Opacity $(\mathrm{nm} / \mathrm{mm})$} & \multicolumn{4}{|c|}{ Water vapor permeability (×104 g/Pa s m) } \\
\hline & & Control & $\begin{array}{c}\text { Locust } \\
\text { bean gum }\end{array}$ & Gellan & Xanthan & Control & $\begin{array}{l}\text { Locust bean } \\
\text { gum }\end{array}$ & Gellan & Xanthan \\
\hline \multirow{2}{*}{$\begin{array}{l}\text { Egg } \\
\text { albumin }\end{array}$} & No oil & $452 \pm 22^{a, d, A}$ & $381 \pm 17^{\text {a, d, D }}$ & $411 \pm 16^{\text {ad, B }}$ & $370 \pm 20$ a, d, C & $1.85 \pm 0.7^{\mathrm{b}, \mathrm{c}, \mathrm{D}}$ & $2.35 \pm 0.6^{\mathrm{b}, \mathrm{c}, \mathrm{A}}$ & $1.93 \pm 0.6^{b, c, c}$ & $2.10 \pm 0.7^{b, c, B}$ \\
\hline & $\begin{array}{l}\text { Emulsified } \\
\text { oil }\end{array}$ & $509 \pm 24$ a, c, A & $407 \pm 18^{a, c, D}$ & $488 \pm 18$ a, c, B & $469 \pm 19$ a, c, c & $1.69 \pm 0.7^{b, d, D}$ & $2.03 \pm 0.8^{b, d, A}$ & $2.19 \pm 0.8^{b, d, C}$ & $2.88 \pm 0.7^{b, d, B}$ \\
\hline \multirow[t]{2}{*}{ Collagen } & No oil & $370 \pm 26$ b, d, A & $341 \pm 15^{b, d, D}$ & $362 \pm 17^{b, d, B}$ & $351 \pm 25$ b, d, C & $2.53 \pm 0.8^{a, c, D}$ & $4.85 \pm 0.9$ a, c, A & $2.94 \pm 0.8^{a, c, c}$ & $3.19 \pm 0.8 \mathrm{a}, \mathrm{c}, \mathrm{B}$ \\
\hline & $\begin{array}{l}\text { Emulsified } \\
\text { oil }\end{array}$ & $431 \pm 14^{b, c, A}$ & $413 \pm 16^{b, c, D}$ & $428 \pm 26^{b, c, B}$ & $421 \pm 19 \mathrm{~b}, \mathrm{c}, \mathrm{C}$ & $2.19 \pm 0.9$ a, d, D & $2.78 \pm 0.8^{a, d, A}$ & $2.31 \pm 0.9$ a, d, c & $2.77 \pm 0.9^{a, d, B}$ \\
\hline
\end{tabular}

a, b Means in same column are not significantly $(\mathrm{P}<0.05)$ different for protein, ${ }^{\mathrm{c}, \mathrm{d}}$ Means in same column are not significantly $(\mathrm{P}<0.05)$ different for emulsion or no emulsion, A, B, C, D Means in same row are not significantly $(P<0.05)$ different for gym type

Table 2: Effect of emulsified oil on protein-gum edible film total soluble material and soluble protein

\begin{tabular}{|c|c|c|c|c|c|c|c|c|c|}
\hline \multirow[t]{2}{*}{ Protein } & \multirow[t]{2}{*}{ Treatment } & \multicolumn{4}{|c|}{ Total soluble material (\%) } & \multicolumn{4}{|c|}{ Soluble protein (\%) } \\
\hline & & Control & $\begin{array}{l}\text { Locust bean } \\
\text { gum }\end{array}$ & Gellan & Xanthan & Control & $\begin{array}{l}\text { Locust bean } \\
\text { gum }\end{array}$ & Gellan & Xanthan \\
\hline \multirow[t]{2}{*}{$\begin{array}{l}\text { Egg } \\
\text { albumin }\end{array}$} & No oil & $\begin{array}{c}31.17 \pm 1.54 \\
b, c, D\end{array}$ & $\begin{array}{c}44.58 \pm 1.75 \\
\text { b, c, A }\end{array}$ & $\begin{array}{c}35.34 \pm 2.98 \\
\text { b, c, B }\end{array}$ & $\begin{array}{c}35.58 \pm 1.68 \\
b, c, c\end{array}$ & $\begin{array}{c}18.94 \pm 1.74 \\
b, c, A\end{array}$ & $\begin{array}{c}10.95 \pm 1.00 \\
b, c, B\end{array}$ & $\begin{array}{c}14.52 \pm 1.49 \\
b, c, c\end{array}$ & $\begin{array}{c}9.36 \pm 0.98 \\
b, c, D\end{array}$ \\
\hline & $\begin{array}{l}\text { Emulsified } \\
\text { oil }\end{array}$ & $\begin{array}{c}28.29 \pm 1.75 \\
b, d, D\end{array}$ & $\begin{array}{c}48.02 \pm 2.03 \\
b, d, A\end{array}$ & $\begin{array}{c}29.02 \pm 1.78 \\
\text { b, d, B }\end{array}$ & $\begin{array}{c}27.70 \pm 2.12 \\
\text { b, d, c }\end{array}$ & $\begin{array}{c}18.65 \pm 1.33 \\
\text { b, d, A }\end{array}$ & $\begin{array}{c}16.00 \pm 1.06 \\
b, d, B\end{array}$ & $\begin{array}{c}16.12 \pm 1.09 \\
b, d, c\end{array}$ & $\begin{array}{c}12.70 \pm 1.13 \\
b, d, D\end{array}$ \\
\hline \multirow[t]{2}{*}{ Collagen } & No oil & $\begin{array}{c}66.29 \pm 1.74 \\
\text { a, c, D }\end{array}$ & $\begin{array}{c}76.59 \pm 2.11 \\
\text { a, c, A }\end{array}$ & $\begin{array}{c}82.22 \pm 2.41 \\
\text { a, c, B }\end{array}$ & $\begin{array}{c}66.41 \pm 2.56 \\
\text { a, c, c }\end{array}$ & $\begin{array}{c}48.17 \pm 2.04 \\
\text { a, c, A }\end{array}$ & $\begin{array}{c}20.56 \pm 1.87 \\
\text { a, c, B }\end{array}$ & $\begin{array}{c}18.20 \pm 1.88 \\
a, c, c\end{array}$ & $\begin{array}{c}17.22 \pm 1.16 \\
a, c, D\end{array}$ \\
\hline & $\begin{array}{l}\text { Emulsified } \\
\text { oil }\end{array}$ & $\begin{array}{c}64.32 \pm 2.11 \\
a, d, D\end{array}$ & $\begin{array}{c}60.37 \pm 1.96 \\
\text { a, d, A }\end{array}$ & $\begin{array}{c}61.17 \pm 3.56 \\
\text { a, d, B }\end{array}$ & $\begin{array}{c}59.97 \pm 3.01 \\
\text { a, d, c }\end{array}$ & $\begin{array}{c}30.54 \pm 1.65 \\
\text { a, d, A }\end{array}$ & $\begin{array}{c}24.28 \pm 1.66 \\
\text { a, d, B }\end{array}$ & $\begin{array}{c}23.70 \pm 156 \\
\text { a, d, c }\end{array}$ & $\begin{array}{c}20.18 \pm 1.11 \\
\text { a, d, D }\end{array}$ \\
\hline
\end{tabular}

${ }^{a, b}$ Means in same column are not significantly $(P<0.05)$ different for protein, ${ }^{c, d}$ Means in same column are not significantly $(P<0.05)$ different for emulsion or no emulsion, $A, B, C, D$ Means in same row are not significantly $(P<0.05)$ different for gym type

in this research are thickeners agents that, irrespectively of their interaction with proteins during edible film manufacture, retain a great amount of water due to their helix folding properties. Locust bean gum is a non ionic polysaccharide with extended two-fold helix structures, and had been used to prepare edible films mixed with other components. Gellan gum naturally forms three-fold helical structures when hydrated, immobilizing water to gel or to form edible membranes with good tensile strength, moisture resistance, and excellent gas-barrier properties. Xanthan gum is a gum polymer with extended five-fold helix structure, and has been employed as well in films manufacture, enhancing starch films properties (Nieto, 2016). These particular features on the structural gum folding resulted in different interactions with proteins and emulsified oil, affecting the total soluble matter and soluble protein.

\section{Puncture force and puncture deformation}

Collagen edible films presented significantly $(\mathrm{P}<0.05)$ higher puncture resistance values than egg white samples. Emulsified edible films were significantly $(\mathrm{P}<0.05)$ more resistant to punch break than samples without emulsified oil. The incorporation of gums into edible films increased rigidity, where significantly $(\mathrm{P}<0.05)$ higher puncture resistance values was observed in gellan gum samples. Control no added gum presented the lower resistance values (Table 3). Puncture deformation was significantly $(\mathrm{P}<0.05)$ higher for collagen samples. The emulsified oil in edible films presented significantly $(\mathrm{P}<0.05)$ higher deformation percent values. Control samples were significantly $(\mathrm{P}<0.05)$ less resistant to break deformation, where gellan gum samples were more resistant (Table 3).

Changes in puncture resistance are due to the disruption of the biopolymer continuous matrix provoking a heterogeneous structure (Soazo et al, 2011). Nonetheless, in edible films containing blends of various biopolymers, as polysaccharides, proteins and/or lipids, there is a developed cooperative functionality taking advantage of each constitutive biopolymer, where a gum which may impart structural cohesion and serve as a structural matrix; a protein which may give rise to a very tight structure by inter- or intra-molecular folding; or a lipid that adds a hydro-repulsive character (Wu et al., 2002). The polysaccharides stabilizing emulsified oil in edible films formulation resulted in more flexible and more stretchable films than those prepared without them.

\section{Tensile strength and percentage of elongation}

Tensile strength values of collagen edible films was significantly $(\mathrm{P}>0.05)$ higher than the egg albumin samples. Emulsified oil in edible films resulted in significantly $(\mathrm{P}<0.05)$ higher values. Inclusion of gums in edible films formulation increased significantly $(\mathrm{P}<0.05)$ edible films tensile strength, with gellan samples as the tougher ones (Table 4). Collagen protein samples were significantly $(\mathrm{P}<0.05)$ more stretchable than egg albumen samples. 
Téllez-Rangel, et al.

Table 3: Effect of emulsified oil on protein-gum edible film puncture resistance and puncture deformation

\begin{tabular}{|c|c|c|c|c|c|c|c|c|c|}
\hline \multirow[t]{2}{*}{ Protein } & \multirow[t]{2}{*}{ Treatment } & \multicolumn{4}{|c|}{ Puncture resistance $(\mathrm{N})$} & \multicolumn{4}{|c|}{ Puncture deformation (\%) } \\
\hline & & Control & $\begin{array}{l}\text { Locust bean } \\
\text { gum }\end{array}$ & Gellan & Xanthan & Control & $\begin{array}{l}\text { Locust bean } \\
\text { gum }\end{array}$ & Gellan & Xanthan \\
\hline \multirow{2}{*}{$\begin{array}{l}\text { Egg } \\
\text { albumin }\end{array}$} & No oil & $0.20 \pm 0.09 \mathrm{~b}, \mathrm{~d}, \mathrm{D}$ & $0.30 \pm 0.01 \mathrm{~b}, \mathrm{~d}, \mathrm{C}$ & $0.90 \pm 0.06^{b, d, A}$ & $0.79 \pm 0.08^{b, d, B}$ & $25.1 \pm 7.4^{b, d, D}$ & $31.6 \pm 6.7^{b, d, C}$ & $32.8 \pm 5.6^{b, d, A}$ & $30.8 \pm 5.9^{b, d, B}$ \\
\hline & $\begin{array}{l}\text { Emulsified } \\
\text { oil }\end{array}$ & $0.52 \pm 0.09 \mathrm{~b}, \mathrm{c}, \mathrm{D}$ & $0.75 \pm 0.09 \mathrm{~b}, \mathrm{c}, \mathrm{c}$ & $1.30 \pm 0.07^{\mathrm{b}, \mathrm{c}, \mathrm{A}}$ & $1.07 \pm 0.08^{b, c, B}$ & $29.8 \pm 7.6^{b, c, D}$ & $35.7 \pm 6.5^{b, c, c}$ & $36.5 \pm 7.8^{\mathrm{b}, \mathrm{c}, \mathrm{A}}$ & $31.3 \pm 4.5^{b, c, B}$ \\
\hline \multirow[t]{2}{*}{ Collagen } & No oil & $1.80 \pm 0.08^{a, d, D}$ & $2.40 \pm 0.34^{a, d, C}$ & $2.34 \pm 0.32^{\text {a, d, A }}$ & $2.55 \pm 0.14 \mathrm{a}, \mathrm{d}, \mathrm{B}$ & $38.5 \pm 8.5^{a, d, D}$ & $3.97 \pm 8.1$ a, d, C & $41.5 \pm 7.5^{\mathrm{a}, \mathrm{d}, \mathrm{A}}$ & $40.1 \pm 8.0^{a, d, B}$ \\
\hline & $\begin{array}{l}\text { Emulsified } \\
\text { oil }\end{array}$ & $2.80 \pm 0.11^{a, c, D}$ & $2.70 \pm 0.21^{a, c, c}$ & $5.15 \pm 0.40$ a, c, A & $3.85 \pm 0.11^{a, c, B}$ & $40.2 \pm 7.8^{\text {a, c, D }}$ & $42.7 \pm 6.7^{a, c, c}$ & $49.5 \pm 6.5^{\text {a, c, A }}$ & $42.5 \pm 7.9$ a, c, B \\
\hline
\end{tabular}

${ }^{a, b}$ Means in same column are not significantly $(P<0.05)$ different for protein, ${ }^{c, d}$ Means in same column are not significantly $(P<0.05)$ different for emulsion or no emulsion, $A, B, C, D$ Means in same row are not significantly $(P<0.05)$ different for gym type

Table 4: Effect of emulsified oil on protein-gum edible film tensile strength and elongation percent

\begin{tabular}{|c|c|c|c|c|c|c|c|c|c|}
\hline \multirow[t]{2}{*}{ Protein } & \multirow[t]{2}{*}{ Treatment } & \multicolumn{4}{|c|}{ Tensile strength $\left(\mathrm{N} / \mathrm{mm}^{2}\right)$} & \multicolumn{4}{|c|}{ Elongation percent (\%) } \\
\hline & & Control & $\begin{array}{l}\text { Locust bean } \\
\text { gum }\end{array}$ & Gellan & Xanthan & Control & $\begin{array}{c}\text { Locust } \\
\text { bean gum }\end{array}$ & Gellan & Xanthan \\
\hline \multirow{2}{*}{$\begin{array}{l}\text { Egg } \\
\text { albumin }\end{array}$} & No oil & $0.38 \pm 0.07^{b, d, D}$ & $0.06 \pm 0.01^{b, d, C}$ & $0.31 \pm 0.06^{b, d, A}$ & $0.63 \pm 0.09 b, d, B$ & $5 \pm 1^{b, d, D}$ & $6 \pm 1^{b, d, c}$ & $7 \pm 1^{b, d}, A$ & $7 \pm 1^{b, d, B}$ \\
\hline & $\begin{array}{l}\text { Emulsified } \\
\text { oil }\end{array}$ & $0.39 \pm 0.04^{b, c, D}$ & $0.36 \pm 0.06^{b, c, c}$ & $0.43 \pm 0.01^{b, c, A}$ & $0.62 \pm 0.04^{b, c, B}$ & $7 \pm 1^{b, c, D}$ & $16 \pm 2^{b, c, c}$ & $14 \pm 2^{b, c, A}$ & $15 \pm 2^{b, c, B}$ \\
\hline \multirow[t]{2}{*}{ Collagen } & No oil & $0.26 \pm 0.04$ a, d, D & $1.12 \pm 0.09^{a, d, c}$ & $1.70 \pm 0.33 \mathrm{a}, \mathrm{d}, \mathrm{A}$ & $1.52 \pm 0.01$ a, d, B & $12 \pm 1$ a, d, D & $30 \pm 5$ a, d, c & $23 \pm 2$ a, d, A & $31 \pm 3$ a, d, \\
\hline & $\begin{array}{l}\text { Emulsified } \\
\text { oil }\end{array}$ & $0.97 \pm 0.06^{a, c, D}$ & $1.41 \pm 0.23^{a, c, c}$ & $3.85 \pm 0.14$ a, c, A & $1.72 \pm 0.00^{a, c, B}$ & $39 \pm 4$ a, c, D & $37 \pm 3^{a, c, c}$ & $31 \pm 2^{a, c, A}$ & $27 \pm 3^{a, c, B}$ \\
\hline
\end{tabular}

${ }^{a, b}$ Means in same column are not significantly $(\mathrm{P}<0.05)$ different for protein, ${ }^{c, d}$ Means in same column are not significantly $(\mathrm{P}<0.05)$ different for emulsion or no emulsion, $A, B, C, D$ Means in same row are not significantly $(P<0.05)$ different for gym type

Emulsified oil in edible films resulted in significantly $(\mathrm{P}<0.05)$ higher elongation percent values. Edible films elongation capacity was significantly $(\mathrm{P}<0.05)$ higher in gum containing samples as well, where higher elongation was observed in gellan gum samples (Table 4).

Polysaccharides plus emulsified oil incorporation changes the structural characteristics of protein edible films. Emulsified oil incorporation resulted in emulsion particle size reduction with the consequent increase in protein chain immobilization in the lipidic interface, increasing maximum tension force (Khwaldia et al., 2004). This resulted in more flexible and stretchable films, due to the discontinuities introduced in the biopolymers network improving tensile properties (Fabra et al., 2008). Edible films tensile parameters changed due to the presence of a lipid phase that disrupts the order within edible film protein matrix, with a plasticizing effect (Galus and Kadzińka, 2016a). The increase in all tensile parameters of emulsified films based is due to strong interaction between the biopolymers and the lipid particles as a cross-linking effect, which decreased the free volume and the molecular mobility of the polymer (Galus and Kadzińka, 2016b).

\section{Fourier transform infra-red spectroscopy and optical microscopy}

FTIR spectra and microphotographs for selected collagen edible films are shown in Fig. 1 (data not shown for egg white edible films). Main changes were relative to the no presence of emulsified oil and different putative interactions between proteins and gums during filmogenic process. Glycerol peak was present in all samples around $1033 \mathrm{~cm}^{-1}$, with slight displacements due to possible interactions between plasticizer and structural components (Bergo and Sobral, 2007). Presence of peaks due to $\mathrm{C}-\mathrm{O}$ stretching and $\mathrm{C}-\mathrm{O}-\mathrm{H}$ stretching, bending and deformation (1200-900 $\mathrm{cm}^{-1}$ ) in fingerprint region can be observed in gum containing samples, in addition to peaks between approximately $1800-2800 \mathrm{~cm}^{-1}$ where the increase in relative intensity corresponds to $\mathrm{C}=\mathrm{O}$ stretching and $\mathrm{C}-\mathrm{H}$ stretching (Coimbra et al., 2010). These changes are related to the presence of gums in collagen edible films. (Fig. 1a, b, and c, for xanthan gum, gellan gum and locust bean gum, respectively). In addition, FTIR spectra of collagen edible films presented changes at the amide band I (around $1652 \mathrm{~cm}^{-1}$ ), in different degree, indicating a possible strong hydrogen bond interaction with added gums in the edible film formulation. Stronger hydrogen bond interaction between collagen and the gums was also reflected in stronger absorption around $1650-1700 \mathrm{~cm}^{-1}$ (Wang et al., 2007b). Another noticeable change was the peaks in the frequency range $2800-3200 \mathrm{~cm}^{-1}$ due to the presence of emulsified oil in edible films (Pérez-Mateos et al., 2009). Maize oil presented higher peaks around 3000 $\mathrm{cm}^{-1} 2925 \mathrm{~cm}^{-1}$ symmetric stretching vibration of aliphatic $\mathrm{CH}_{2}$ group, $2962 \mathrm{~cm}^{-1}$ symmetric and asymmetric vibration of aliphatic $\mathrm{CH}_{3}$, and $\mathrm{C}-\mathrm{H}$ stretching vibration of cisdouble bond $3005 \mathrm{~cm}^{-1}$ ) (Vlachos et al., 2006). Control 


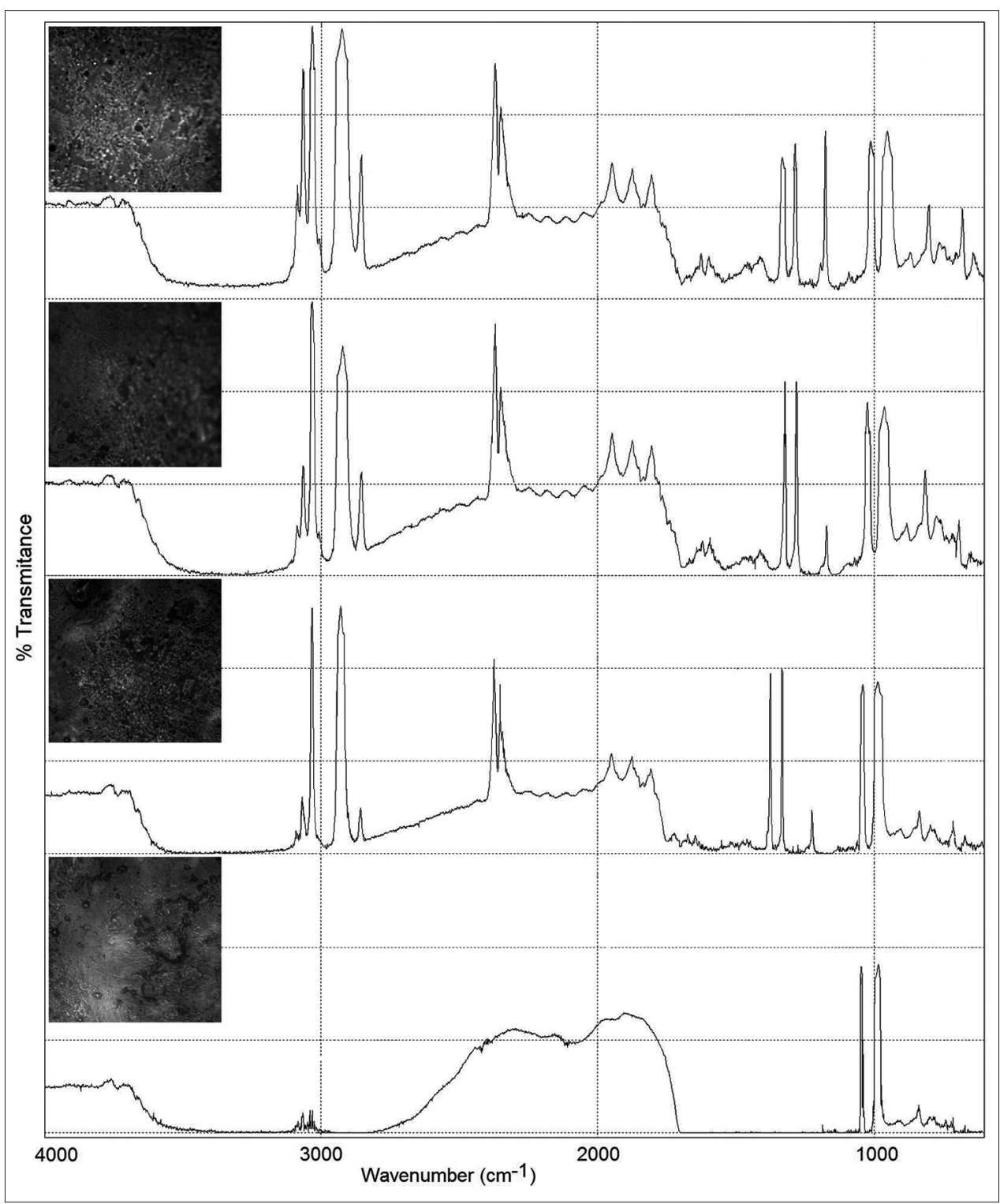

Fig 1. FTIR spectra and optical micrographs (50x) for collagen edible films and: a) xanthan gum with emulsified oil, b) gellan gum with emulsified oil, c) locust bean gum with emulsified oil, and d) control (no gum, no emulsified oil).

sample with no added emulsified oil (Fig. 1d) lacks of these peaks. Proteins presented as well a broad band above $3500 \mathrm{~cm}^{-1}$ range, related to free and bound $\mathrm{O}-\mathrm{H}$ and $\mathrm{N}-\mathrm{H}$ groups, which are able to form hydrogen bonding with the carbonyl group of the peptide linkage in the protein (Guerero et al., 2010). For carbohydrates, spectroscopic regions from $3550-3200 \mathrm{~cm}^{-1}$ and $3650-3580 \mathrm{~cm}^{-1}$ correspond to $\mathrm{O}-\mathrm{H}$ stretching (Coimbra et al., 2010) as well. In gum containing edible films the increase in relative intensity within this region correspond to interactions between proteins and polysaccharides stabilizing maize oil.

Structural differences between different treatments can be observed in optical micrographs. When emulsified oil was incorporated in the edible films elaborated with different gums, the films pattern was practically the same rough surface, with exception of control sample with a smooth appearance. Samples containing gums and emulsified oil appear to be even distributed, with similar random alignment of corpuscular crumbled surface. Sample with xanthan gum seems to present a more granulated and homogeneous porous structure (Fig. 1a). When gellan gum was present in edible films, a similar pattern can be observed, formed as well by clustered particles and small cavities (Fig. 1b). Samples with locust bean gum presented less homogeneity, with large areas with apparently bigger cavities (Fig. 1c). Control edible film without emulsified oil and no gum showed a homogeneous structure but with a fine granulated appearance (Fig. 1d).

Despite of the fact that collagen and egg white albumin presented different characteristics related to water vapor 
permeability and mechanical properties, the effect provoked by the different gums employed seems to follow the same tendency, i.e., charged polysaccharides, gellan gum or xanthan gum, enhanced edible film properties, as compared to no-charged polysaccharide, as locust bean gum, where other kind of interactions different to electrostatic ones occurred. In non-charged locust bean gum, fragments of its long chain promoting interactions among collagen chains tightening the network structure, forming intermolecular hydrogen bonds and van der Walls forces due to the presence of several hydroxyl groups in locust bean gum molecule that influences the possibility of non covalent multipoint interaction with collagen (Kanungo et al., 2014). In contrast, conformational changes that xanthan gum suffered during heating and cooling provoked cooperative conformation transition to a rigid ordered structure (transition range $50-60{ }^{\circ} \mathrm{C}$, temperatures employed during collagen films elaboration), affecting collagen properties in suspension, resulting in a more homogeneous structure, increasing gel strength in gelled systems (Nicoleti and Telis, 2009). For gellan gum, the anionic domains in gellan molecule interacts with the cationic domains of collagen (fish gelatin), strengthening the film structure (Pranoto et al., 2007).

\section{CONCLUSION}

At the experimental conditions employed, the physical and mechanical properties of protein edible films can be manipulated in order to modify water vapor permeability and puncture/tension resistance. On one hand, gums increased WVP and improved mechanical properties. On other hand, emulsified oil decreased WVP and reduced mechanical resistance. The incorporation of emulsified oil affected as well WVP, modifying the hydrophilic character of the protein-gum structure, decreasing WVP. Charged polysaccharides (gellan gum and xanthan gum) allowed a strong interaction with proteins, improving mechanical properties, increasing WVP and reducing edible film solubility. Non-charged locust bean gum presented other kind of interactions resulting in less cohesive and resistant structure. Gums as thickener agent during and after maize oil emulsion resulted in structural changes that improved edible films mechanical properties, to facilitate cut and handling.

\section{REFERENCES}

Bergo, P. and P J. L. Sobral. 2007. Effects of plasticizer on physical properties of pigskin gelatin films. Food Hydrocoll. 21: 1285-1289.

Coimbra, M. A., A. Nunes, A. S. Barros and I. Delgadillo. 2010. The potential of mid-infrared spectroscopy for monitoring changes in polysaccharides and other carbohydrates during processing.
In: E. Li-Chan, P. R. Griffiths and J. M. Chalmers. (Eds.), Applications of Vibrational Spectroscopy in Food Science. John Wiley \& Son, New York, pp. 261-270.

de Kruif, C. G. and R. Tuinier. 2001. Polysaccharide protein interactions. Food Hydrocoll. 15: 555-563.

Der, G. and B. S. Everitt. 2002. A Handbook of Statistical Analyses Using SAS. Chapman \& Hall, London, pp. 98-119.

Díaz, P., C. Arratia, C. Vásquez, F. Osorio and J. Enrione. 2011. Effect of glycerol on water sorption of bovine gelatin films in the glassy state. Proc. Food Sci. 1: 267-274.

Doublier, J. L., C. Garnier, D. Renard and C. Sanchez. 2000. Protein-polysaccharide interactions. Curr. Opin. Colloid Interface Sci. 5: 202-214.

Fabra, M. J., P. Talens and A. Chiralt. 2008. Effect of alginate and $\lambda$-carrageenan on tensile properties and water vapour permeability of sodium caseinate-lipid based films. Carbohydr. Polym. 74: 419-426.

Fernández-Pan, I., J. Ignacio and M. Caballero. 2011. Biopolymers for edible films and coatings in food applications. In: D. Plackett (Ed.), Biopolymers-New Materials for Sustainable Films and Coatings. John Wiley \& Sons, New York, pp. 233-254.

Galus, S. and J. Kadzińska. 2015. Food applications of emulsion-based edible films and coatings. Trends Food Sci. Technol. 45: 273-283.

Galus, S. and J. Kadzińska. 2016a. Whey protein edible films modified with almond and walnut oils. Food Hydrocoll. 52: 78-86.

Galus, S. and J. Kadzińska. 2016b. Moisture sensitivity, optical, mechanical and structural properties of whey protein-based edible films incorporated with rapeseed oil. Food Technol. Biotechnol. 54: 78-89.

Gennadios, A., C. L. Weller and R. F. Testin. 1993. Modification of physical and barrier properties of edible wheat gluten-based films. Cereal Chem. 70: 426-429.

Gennadios, A., C. L. Weller, M. A. Hanna and G. W. Froning. 1996. Mechanical and barrier properties of egg albumen films. J Food Sci. 61: 585-589.

Giancone, T., E. Torrieri, P. Di Pierr, L. Mariniello, M. Moresi, R. Porta and P. Masi. 2008. Role of constituents on the network formation of hydrocolloid edible films. J. Food Eng. 89: 195-203.

Gornall, A. G., C. J. Bardawill and M. M. David. 1949. Determination of serum proteins by means of the biuret reaction. J. Biol. Chem. 177: 751-766.

Guerero, P., A. Retegi, N. Gabilondo and K. de la Caba. 2010. Mechanical and thermal properties of soy protein films processed by casting and compression. J. Food Eng. 100: 145-151.

Habig McHugh, T., F. I. Avena-Bustillos and J. M. Krochta. 1993. Hydrophilic edible films: Modified procedure for water vapor permeability and explanation of thickness effects. J. Food Sci. 58: 899-903.

Hagenmaier, R. D. 2012. Gas-exchange properties of edible films and coatings. In: E. A. Baldwin, R. D. Hagemmaier and J. Bai (Eds.), Edible Coating and Films to Improve Food Quality, 2nd ed. CRC Press, Boca Raton.

Handa, A., A. Gennadios, G. W. Froning, N. Kuroda and M. A. Hanna. 1999. Tensile, solubility, and electrophoretic properties of egg white films as affected by surface sulfhydryl groups. J. Food Sci. 64: 82-85.

Jangchud, A. and M. S. Chinnan. 1999. Peanut protein film as affected by drying temperature and $\mathrm{pH}$ of film forming solution. J. Food Sci. 64: 153-157. 
Kanungo, I., N. N. Fathima, R. R. Jonnalagadda and B. U. Nair. 2014. Elucidation of hydration dynamics of locust bean gum-collagen composites by impedance and thermoporometry. Carbohydr. Polym. 103: 250-260.

Khwaldia, K., S. Banon, S. Desobry and J. Hardy. 2004. Mechanical and barrier properties of sodium caseinate-anhydrous milk fat edible films. Int. J. Food Sci. Technol. 39: 403-411.

Kokoszka, S., F. Debeaufort, A. Lenarta and A. Voilley. 2010. Liquid and vapour water transfer through whey protein/lipid emulsion films. J. Sci. Food Agric. 90: 1673-1680.

Lacroix, M., and C. Le Tien. 2005. Edible films and coatings from nonstarch polysaccharides. In: J. Han (Ed.), Innovations in Food Packaging, Academic Press, New York.

Lee, K. Y., J. Shim and H. G. Lee. 2004. Mechanical properties of gellan and gelatin composite films. Carbohydr. Polym. 56: 251-254.

Martin-Polo, M., C. Mauguin and A. Voilley. 1992. Hydrophobic films and their efficiency against moisture transfer. 1. Influence of the film preparation technique. J. Agric. Food Chem. 40: 407-412.

Martins, J. T., M. A. Cerqueira, A. I. Bourbon, A. C. Pinheiro, B. W. S. Souza and A. A. Vicente. 2012. Synergistic effects between $\mathrm{K}$-carrageenan and locust bean gum on physicochemical properties of edible films made thereof. Food Hydrocoll. 29: 280-289.

Nicoleti, J. F. and V. R. N. Telis. 2009. Viscoelastic and thermal properties of collagen-xanthan gum and collagen-maltodextrin suspensions during heating and cooling. Food Biophys. 4: 135-146.

Nieto, M. B. 2016. Edible film and packaging using gum polysaccharides. In: M. Cerqueira, R. N. Pererira, O. L. Ramos, J. A. Teixeira and A. Vicente (Eds.), Edible Food Packaging Materials and Processing Technologies. CRC Press, Boca Raton, pp. 9-79.

Nussinovith, A. 1997. Hydrocolloid Applications. Springer-Science, New York.

Pavlath, A. E. and W. Orts. 2009. Edible films and coatings: Why, what, and how? In: M. E. Embuscado and K. C. Huber (Eds.), Edible Films and Coatings for Food Applications. Springer Science, New York, pp. 1-23.

Pereda, M., G. Amica and N. Marcovich. 2012. Development and characterization of edible chitosan/olive oil emulsion films. Carbohydr. Polym. 87: 1318-1325.

Pérez-Gago, M. B. 2012. Películas comestibles compuestas a base de hidrocoloides y lípidos. In: G. L. Olivas-Orozco, G. A. GonzálezAguilar, O. Martín-Belloso and R. Soliva-Fortuny. (Eds.), Películas y Recubrimientos Comestibles: Propiedades y Aplicaciones en Alimentos. AM Editores, Mexico City, pp. 219-241.
Pérez-Mateos, M., P. Montero and M. C. Gómez-Guillén. 2009. Formulation and stability of biodegradable films made from cod gelatin and sunflower oil blends. Food Hydrocoll. 23: 53-61.

Pranoto, Y., C. M. Lee and J. H. Park. 2007. Characterizations of fish gelatin films added with gellan and k-carrageenan. LWT Food Sci. Technol. 40: 766-774.

Schmitt, C., C. Sanchez, S. Desobry-Banon and J. Hardy. 1998. Structure and technofunctional properties of protein-polysaccharide complexes: A review. Crit. Rev. Food Sci. Nutr. 38: 689-753.

Soazo, M., A. Rubiolo and R. Verdini. 2011. Effect of drying temperature and beeswax content on physical properties of whey protein emulsion films. Food Hydrocoll. 25: 1251-1255.

Sobral, P. D. A. F. C. Menegalli, M. D. Hubinger and M. A. Roques. 2001. Mechanical, water vapor barrier and thermal properties of gelatin based edible films. Food Hydrocoll. 15: 423-432.

Tural, S. and S. Turhan. 2017. Properties and antioxidant capacity of anchovy (Engraulis encreasicholus) by-product protein films containing thyme essential oil. Food Technol. Biotechnol. 55: 77-85.

Veiga-Santos, P., L. L. M. Oliveira, M. P. Cereda, A. J. Alves and A. R. P. Scamparini. 2005. Mechanical properties, hydrophilicity and water activity of starch-gum films: effect of additives and deacetylated xanthan gum. Food Hydrocoll. 19: 341-349.

Vlachos, N., Y. Skopelitis, M. Psaroudaki and E. Tegou. 2006. Application of Fourier transform-infrared spectroscopy to edible oils. Anal. Chim. Acta. 573-574: 459-465.

Wang, B., D. Y. Jia, S. Q. Raun, S. Qin. 2007a. Structure and properties of collagen-konjac glucomannan-sodium alginate blend films. J. Appl. Polym. Sci. 106: 327-332.

Wang, L., L. Liu, J. Holmes, J. F. Kerry and J. P. Kerry. 2007b. Assessment of film-forming potential and properties of protein and polysaccharide-based biopolymer films. Int. J. Food Sci. Technol. 42: 1128-1138.

Wu, Y., C. L. Weller, F. Hamouz, S. L. Cuppett and M. Schnepf. 2002. Development and application of multicomponent edible coatings and films: A review. Adv. Food Nutr. Res. 44: 347-394.

Yang, L., and A. T. Paulson. 2000. Effects of lipids on mechanical and moisture barrier properties of edible gellan film. Food Res. Int. 33: 571-578.

Zaritzky, N. 2011. Edible coatings to improve food quality and safety. In: J. M. Aguilera, G. V. Barbosa-Cánovas, R. Simpson, J. WeltiChanes and D. Bermúdez-Aguirre (Eds.), Food Engineering Interfaces. Springer, New York, pp. 631-659. 